\title{
DIVERSIFICATION BENEFITS IN THE FINNISH COMMERCIAL PROPERTY MARKET
}

\author{
Heidi FALKENBACH \\ Helsinki University of Technology, Real Estate Research Group, \\ P.O. Box 1200, FIN-02015 TKK, Finland \\ E-mail: heidi.falkenbach@tkk.fi
}

Received 11 September 2008; accepted 12 January 2009

\begin{abstract}
The Finnish commercial property market internationalised rapidly in the beginning of the $21^{\text {st }}$ century. According to the portfolio theory and previous research on international property investments, the main motivation factor driving international real estate investments is the possibility to reach diversification benefits. The paper discusses the diversification benefits offered by the Finnish property market in its early years of internationalisation. As international real estate investors in the Finnish property market include investors with both real estate only, as well as mixed-asset portfolios, the diversification benefits are studied both in terms of a Finnish mixed-asset portfolio, as well as international real estate portfolio.
\end{abstract}

KEYWORDS: Property portfolio; Mixed-asset portfolio; Real estate; International diversification; Finland

\section{INTRODUCTION}

Internationalisation of the European real estate market has been a growing trend of the millennium, the cross boarder investments accounting for 63\% in 2007 (Jones Lang Lasalle, 2007). This trend reached the Finnish property market in 1998, when the first international real estate investments were conducted by an opportunistic U.S. investor. The internationalisation took off, however, only in 2002, when 7 international investors entered the Finnish market (Catella, 2005). Today, cross border investments represent about a half of the yearly transactions volume in the Finnish commercial real estate markets, and more than 70 international investors have entered the market. (KTI, 2008; Catella, 2008a).
Modern portfolio theory (Markowitz, 1952) suggests that investors base their asset allocation decisions on the risk-return characteristics of the asset returns, as well as on the co-movement of the asset returns, and thereby provided diversification benefits. The objective of gaining diversification benefits has been shown as the main motivating factor driving also international real estate investments. The early questionnaire surveys by Worzala (1994) and Newell and Worzala (1995) confirm that the primary reasons for investors to invest in international real estate are diversification benefits and possibilities to achieve higher returns. As other important rationales the respondents had chosen e.g. the lack of domestic investment opportunities, currency strength, diversification benefits due to differ- 
ent economic and political environments, the ability to invest in property-specific feature that are different from domestic opportunities, matching investments to liabilities and the low correlation between the asset returns in the countries (Worzala and Newell, 1997). Similarily, McAllister (1999) showed that the potential benefits U.K. investors saw in international property investments were diversification, high returns, liability matching and support to core business. The aim of this paper is to determine, if the Finnish commercial real estate market provided diversification benefits in its early years of internationalisation. As international real estate investors in the Finnish property markets include investors with both real estate only, as well as mixed-asset portfolios, the diversification benefits are studied both in terms of a Finnish mixed-asset portfolio, as well as an international real estate portfolio.

The international investors in the Finnish property markets represent a broad range in terms of their origin, type and investment strategies. Figure 1 shows the international investors by their country of origin. More then $80 \%$ of the international investors in the Finn-

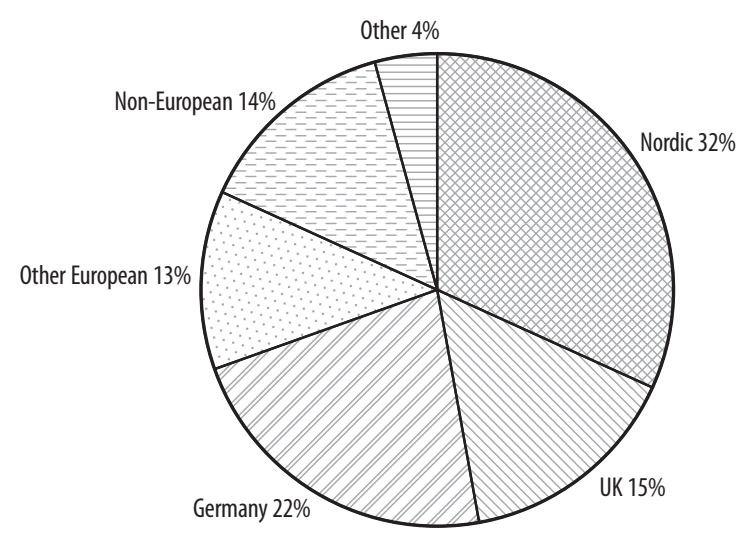

Figure 1. International investors in Finnish property markets, represented by their country of origin (Source of data: Catella, 2008b) ish property markets were of European origin, most commonly from other Nordic countries (32\%), Germany (22\%) and U.K. (15\%). The investors from outside Europe were either from the U.S. or Israel, and the group "other" includes investors with more than one country of origin.

A possible explanation for the strong representation of European, and especially Nordic, investors in the group of international investors in the Finnish markets are the challenges related to international investment. In the questionnaire surveys of Worzala (1994), and Newell and Worzala (1995) the respondents identified as most important problems of international property investment the lack of local expertise, inability to identify acquisitions in a foreign market, taxation differences, potential for misunderstandings due to language and cultural differences as well as the management and operation once investment is made. Again, the survey of McAllister (1999) confirms that investors regard the information costs and high costs of diversification as the main problems associated with foreign real estate investments. Thus, European investors might feel that the information-related risks are lower when investing within the same continent. The Nordic countries, on the other hand, share similar legal structures, and the cultural differences between the countries are low.

The following chapter presents the research conducted in the field of diversification benefits in international property portfolios. Thereafter the data and methods used in the analysis, and possible limitations related to them are discussed. The results of the analysis of diversification benefits provided by the Finnish market are discussed separately for Finnish mixed asset portfolio and international real estate portfolio. The last section draws the conclusions and gives suggestions for further research. 


\section{LITERATURE REVIEW}

The benefits of including real estate in a mixed-asset portfolio including financial assets, most commonly stocks, bonds, and real estate, has been extensively studied during the past two decades. Seiler et al. (1999) provide a review of the early studies summarising that property has a low correlation with other asset classes, and thus should have a place in a mixed asset portfolio. Due to the data availability issues most of the early studies analysing mixed asset portfolio are performed on U.S. and U.K. data, the amount of research being more limited in the continental Europe. For more recent studies in Europe, Hoesli et al. (2004) provide an analysis of benefits of including real estate in mixed-asset portfolio using the perspectives of seven countries: Australia, France, the Netherlands, Sweden, Switzerland, U.K. and U.S. According to their analysis, property investments provided diversification benefits in all of the studied markets, the optimal allocation to real estate varying depending on the risk level and country, being on the 5 to $15 \%$ range for unhedged returns and in the rage of 15 and $25 \%$ for hedged returns.

A large part of the investors investing in international real estate, however, have a real estate only portfolio. Among the early studies on international diversification benefits in real estate portfolios is that of Wurtzebach (1991). He evaluated the diversification benefits of a property portfolio consisting of equal allocations of office investments in London, Frankfurt, New York, Paris and Sydney markets. All returns were measured in local currency. The diversification benefits were measured through reduced volatility of vacancy rate, rental values, capitalisation rate and projected rates of return. The international diversification reduced the volatility of each component compared to the portfolio consisting of only U.S. real estate. In comparison to each of the indi- vidual markets, the results were more varied, but in many of the cases international diversification reduced the volatility of the portfolios.

Gordon (1991) analysed the diversification benefits for an investor holding U.S. and U.K. real estate, concluding that the investor would benefit from the international exposure. The analysis was conducted based on local currencies. Also Worzala (1992) studied the diversification benefits of U.K. and U.S. real estate, finding gains from international diversification benefits. She performs the analysis with and without taking the currency fluctuations into account, and notes that the level of diversification benefits is higher if local returns are used. A similar, pair-wise country analysis is provided by Hudson-Wilson and Stimpson (1996), who analyse the diversification benefits of including U.S. real estate in a Canadian investors' portfolio. The diversification benefits were analysed by comparing a portfolio of only Canadian real estate to a portfolio holding up to $20 \%$ U.S. real estate. The analysis is conducted in returns denominated in Canadian dollars, i.e. assuming unhedged returns. The analysis of incorporating U.S. assets into the portfolio in conducted in three stages: first, analysing the benefits of incorporating aggregate U.S. real estate; second, analysing the benefits of incorporating various U.S. property types; and third, analysing the benefits of incorporating property from individual U.S. cities into the portfolio. The authors conclude that international diversification was beneficial, in all of the three studied levels. The authors conduct the analysis also based on returns in local currencies and due to the differences in results, suggest, that currency risk might have a substantial effect on the investment.

Addae-Dapaah and Yong (1998) study the international diversification benefits of international office investments in Asia-Pacific from Singaporean investor's perspective. The authors find substantial diversification benefits in international property investments. The 
authors also study the significance of currency risk on the returns and correlation coefficients, concluding that the impact of exchange rate volatility is marginal.

Case et al. (1999) analyse the property returns in 22 markets from 21 countries. They use returns converted to U.S. dollars, to reflect the U.S. investor's point of view. The authors find diversification benefits in international property investments, but note that the level of diversification gains depends from the property type included in the portfolio. They also find that property returns are dependent of the global GDP changes, which limits the benefits obtainable through international diversification of property investments.

Addae-Dapaah and Yong (2000) study the effectiveness of international diversification in the context of Asia-Pacific real estate from a Singaporean investor's perspective. Their analysis, which is conducted both for local returns and on returns denominated in one currency, shows that diversification benefits existed over the reference period from 1984 to 1996, and were the highest for retail property. A more recent analysis of the international diversification benefits in Asia-Pacific market is provided by Jin et al. (2007). They create efficient portfolios of both individual asset classes (incl. real estate) and a mixed-asset portfolio of 11 countries in the area, using U.S. dollar denominated returns. The analysis shows diversification benefits for the international property portfolio.

Lim et al. (2008) provide an analysis of the correlation of property returns in 15 countries, including Finland, based on the IPD property index data. Their analysis suggests that the correlations between the property returns in the countries vary significantly, from almost complete correlation (99\%) between some of the studied countries to high negative correlations between some. Thus the diversification benefits obtainable vary markedly depending on the markets studied.

\section{DATA AND METHODS}

The study uses annual data on Finnish stocks, bonds, direct real estate and indirect real estate as well as annual real estate return data on fifteen property markets: Canada, Denmark, Finland, France, Germany, Ireland, Netherlands, Norway, Portugal, Spain, Sweden, Switzerland, U.K. and U.S. for the time period 2002-2006, i.e. the first five years where international investors have been present on the Finnish property market.

The returns of Finnish assets were obtained from KTI Finland. The bonds returns are based on EFFAS Finland Government Bond Index. Stock index is the OMX Helsinki Cap gross index and indirect property index the OMX Helsinki Real Estate gross index. All returns are total returns including income returns and capital appreciation. Finnish direct real estate returns were obtained from KTI Index, an IPD-compliant property index. International property returns are All Propertyindices obtained from IPD Multinational Index Spreadsheet. International diversification benefits are analysed by using unhedged returns, as well as Euro-dominated returns.

The use of index-based property data has some drawbacks that should be taken into account when conducting the analysis. Firstly, indices reflect the investment policy of institutional investors in the country in question. Thus, the divisions between e.g. property types vary between countries (Hoesli et al., 2004). Secondly, as indices are constructed of the returns of a large amount of properties, they reflect the returns of a well-diversified portfolio. This assumption might be violated in case of international investors entering a new market. And thirdly, as most of the IPD indices are appraisal-based, they are affected by valuation smoothing. The phenomenon leads to the standard deviation of time series to be underestimated and also affects the correlations of asset returns (see e.g. Geltner, 1989, 1993; 
Diaz and Wolverton, 1998). There are several methods for correcting, i.e. de-smoothing, the time series to track the true volatility of property data. The shortness of the time series used in this study, however, makes the correction for the bias difficult, as the data does not cover a total cycle. Thus, no corrections for valuation smoothing were performed on the data.

This study analyses the diversification benefits provided by the Finnish real estate market using the Modern Portfolio Theory (MPT), a framework by Markowitz (1952). However, unlike most studies using MPT, this study focuses on analysing historical returns and diversification benefits. The use of ex-post data has the benefit of avoiding future predictions of the asset returns, especially in the case where the data period is too short to cover an entire business cycle. The optimisation applies a no short-selling constraint, i.e. all asset allocations in optimal portfolios must be zero or larger, and all asset weights must sum to one.

The application of mean-variance optimisation often leads to the creation of portfolios with corner solutions, i.e. few assets enjoying very large allocations and the other having zero allocations (Black and Littermann, 1992). To encounter the problem, the optimisation of international real estate portfolio is conducted in two stages. First, unconstrained optimal portfolios are created. To avoid extreme allocations in individual countries, the second stage of optimisation was conducted using a $20 \%$ maximum allocation constraint for each country.

\section{DIVERSIFICATION BENEFITS IN THE FINNISH MARKET}

\subsection{Finnish mixed asset portfolio}

The analysis of diversification benefits begins with an analysis of a mixed asset portfolio consisting of only Finnish assets, i.e. Finnish stocks, bonds, returns on investments in public real estate investment company shares ( $\mathrm{RE}$ stocks) and real estate. If an investor is indif- ferent of the division of his asset into different asset classes, but prefers a country exposure, the mixed-asset portfolio offers insights in seeing if investors should invest in Finnish real estate at all. The property-related risk factors omitted by MPT, i.e. the lumpy nature of the asset class combined with the small size and thus rather low liquidity of the Finnish property market imply that should the optimal mean-variance portfolio not include real estate, the investor would prefer investing his wealth into stocks and bonds.

The descriptive statistics of the asset returns are given in Table 1. As typical, the average return on direct real estate was between that of stocks and bonds. Interestingly, the returns on $\mathrm{RE}$ stocks were markedly higher, more than five times the returns on direct real estate and doubled the return on stocks. The volatility of asset returns is illustrated by standard deviation and by coefficient of variation, which measures the ratio of standard deviation to average return, i.e. the average risk per unit of return. The coefficient of variation was the lowest for direct and indirect real estate. In comparison to those, the coefficient of variation was surprisingly high for bonds, whereas stocks carried, as expected, by far the most risk per unit of return.

Table 1. Descriptive statistics and correlation matrix for Finnish asset returns

\begin{tabular}{|c|c|c|c|c|}
\hline & Stocks & Bonds & RE stocks & $\mathrm{RE}$ \\
\hline $\begin{array}{l}\text { Average } \\
\text { return }\end{array}$ & $19,00 \%$ & $4,92 \%$ & $38,82 \%$ & $6,95 \%$ \\
\hline $\begin{array}{l}\text { Standard } \\
\text { deviation }\end{array}$ & $18,94 \%$ & $3,46 \%$ & $15,96 \%$ & $1,94 \%$ \\
\hline $\begin{array}{l}\text { Coefficient } \\
\text { of variation }\end{array}$ & 1,00 & 0,7 & 0,41 & 0,28 \\
\hline Correlations & Stocks & Bonds & RE stocks & $\mathrm{RE}$ \\
\hline Stocks & 1 & & & \\
\hline Bonds & $-0,86$ & 1 & & \\
\hline RE stocks & 0,54 & $-0,85$ & 1 & \\
\hline $\mathrm{RE}$ & 0,53 & $-0,83$ & 0,75 & 1 \\
\hline
\end{tabular}


In addition to the return levels, correlation coefficients of asset returns are of importance when choosing the structure of a portfolio. The smaller the correlation coefficient, the larger the diversification benefits. The correlation matrix for Finnish asset returns is illustrated in lower part of Table 1. As shown in the table, Finnish bonds had a high negative correlation with all the other asset classes studied, suggesting significant diversification benefits. The correlation between stocks and direct real estate, as well as stocks and RE stocks, was positive, suggesting limited diversification benefits. The correlation between direct real estate and $\mathrm{RE}$ stocks was high and positive; suggesting that diversification within the real estate asset class did not provide diversification benefits, but that they could have been close substitutes within the studied time period.

The structure of efficient portfolios is illustrated in Table 2. As could be expected from the risk-return structure and correlation characteristics, RE stocks dominate the efficient portfolio in all but the lowest return levels. Bonds enter the efficient portfolios only at the lowest return levels, whereas stocks are present at the medium to high return levels. Direct real estate enters the efficient portfolio at return level of $16 \%$. The allocation decreases from this maximum of almost $70 \%$ to zero at return levels of $36 \%$.

The results of the portfolio optimisation differ from most of the empirical research, where direct real estate is typically characterised of having a high allocation in the portfolios with low return and risk. This can be explained by the exceptional risk-return characteristics of $\mathrm{RE}$ stocks under the study period and the relatively poor risk-return trade-off of stock and bonds returns.

As mentioned earlier, the results of the analysis might be biased due to the appraisalsmoothing phenomenon. The bias on the optimal allocation is expected to be larger in the mixed-asset portfolio than in the international real estate only portfolio, because in the mixed-

Table 2. Asset allocation in efficient mixed-asset portfolios

\begin{tabular}{llllll}
\hline \multirow{2}{*}{ Portfolio return } & Standard deviation & \multicolumn{3}{l}{ Allocation } & \\
\cline { 3 - 5 } & & Stocks & Bonds & RE Stocks & RE \\
\hline $6 \%$ & $3,48 \%$ & $0,0 \%$ & $96,8 \%$ & $3,2 \%$ & $0,0 \%$ \\
$8 \%$ & $3,68 \%$ & $0,0 \%$ & $90,9 \%$ & $9,1 \%$ & $0,0 \%$ \\
$10 \%$ & $4,09 \%$ & $0,0 \%$ & $85,0 \%$ & $15,0 \%$ & $0,0 \%$ \\
$12 \%$ & $4,66 \%$ & $0,0 \%$ & $79,1 \%$ & $20,9 \%$ & $0,0 \%$ \\
$14 \%$ & $5,32 \%$ & $1,0 \%$ & $72,6 \%$ & $26,4 \%$ & $0,0 \%$ \\
$16 \%$ & $5,14 \%$ & $3,5 \%$ & $0,0 \%$ & $27,1 \%$ & $69,5 \%$ \\
$18 \%$ & $6,01 \%$ & $5,5 \%$ & $0,0 \%$ & $32,6 \%$ & $61,9 \%$ \\
$20 \%$ & $6,87 \%$ & $7,5 \%$ & $0,0 \%$ & $38,1 \%$ & $54,4 \%$ \\
$22 \%$ & $7,74 \%$ & $9,6 \%$ & $0,0 \%$ & $43,6 \%$ & $46,8 \%$ \\
$24 \%$ & $8,61 \%$ & $11,6 \%$ & $0,0 \%$ & $49,1 \%$ & $39,3 \%$ \\
$26 \%$ & $9,49 \%$ & $13,7 \%$ & $0,0 \%$ & $54,6 \%$ & $31,7 \%$ \\
$28 \%$ & $10,37 \%$ & $15,7 \%$ & $0,0 \%$ & $60,1 \%$ & $24,2 \%$ \\
$30 \%$ & $11,24 \%$ & $17,7 \%$ & $0,0 \%$ & $65,6 \%$ & $16,6 \%$ \\
$32 \%$ & $12,12 \%$ & $19,8 \%$ & $0,0 \%$ & $71,1 \%$ & $9,1 \%$ \\
$34 \%$ & $13,00 \%$ & $21,8 \%$ & $0,0 \%$ & $76,6 \%$ & $1,5 \%$ \\
$36 \%$ & $14,00 \%$ & $14,2 \%$ & $0,0 \%$ & $85,8 \%$ & $0,0 \%$ \\
$38 \%$ & $15,33 \%$ & $4,1 \%$ & $0,0 \%$ & $95,9 \%$ & $0,0 \%$ \\
\hline
\end{tabular}


asset portfolio case direct real estate is the only asset that is exposed to the phenomenon. As the shortness of time series would limit the reliability of de-smoothing procedures, the effect of volatility increases were simply tested by doubling the standard deviation of the direct property returns, which gives a rough picture of the sensitivity of the result to asset volatility changes, but unfortunately does not take into account the change in correlation structures. In this case the increase in standard deviation leads to real estate entering the efficient portfolios later, at the return level of $22 \%$. Between the return levels of 22 and $34 \%$ changes in the optimal allocation remained small, at less that $0,6 \%$. It should be noted, however, that even with the doubled property return volatility the coefficient of variation of property returns was still lower than for bonds.

\subsection{International real estate portfolio}

\section{Hedged returns}

The second part of the analysis focuses on Finnish real estate investments in an international real estate portfolio. The analysis is started with returns in local currencies, which corresponds to the situation where the investor has hedged all the risks of currency fluctuations.

Table 3 presents the descriptive statistics of property returns in the studied property markets during 2002-2006. Concentrating only on the average returns measured in local currencies, the Finnish property market was not that attractive during the observation period. The level of Finnish property returns was below the average $(10,6 \%)$, and third lowest of the countries studied. The highest returns were provided by the Irish and U.K. markets, where the return levels exceeded $15 \%$.

In respect to the risk-return trade-off the Finnish market was more attractive, the coefficient of variation being the third lowest in the dataset. Extremely low coefficient of variation was provided by the Swiss market, which is
Table 3. Summary statistics of property data (hedged returns)

\begin{tabular}{llll}
\hline Country & $\begin{array}{l}\text { Average } \\
\text { return }\end{array}$ & $\begin{array}{l}\text { Standard } \\
\text { deviation }\end{array}$ & $\begin{array}{c}\text { Coefficient } \\
\text { of variation }\end{array}$ \\
\hline Canada & $13,49 \%$ & $5,04 \%$ & 0,37 \\
Denmark & $11,85 \%$ & $5,63 \%$ & 0,48 \\
Finland & $6,95 \%$ & $1,93 \%$ & 0,28 \\
France & $12,79 \%$ & $5,79 \%$ & 0,45 \\
Germany & $1,95 \%$ & $1,42 \%$ & 0,73 \\
Ireland & $15,56 \%$ & $10,18 \%$ & 0,65 \\
Netherlands & $9,29 \%$ & $2,16 \%$ & 0,23 \\
Norway & $11,56 \%$ & $4,67 \%$ & 0,40 \\
Portugal & $11,24 \%$ & $1,64 \%$ & 0,15 \\
Spain & $12,48 \%$ & $4,44 \%$ & 0,36 \\
Sweden & $7,58 \%$ & $6,63 \%$ & 0,87 \\
Switzerland & $5,39 \%$ & $0,35 \%$ & 0,06 \\
U.K. & $15,21 \%$ & $4,56 \%$ & 0,30 \\
U.S. & $13,38 \%$ & $5,46 \%$ & 0,41 \\
\hline
\end{tabular}

interesting, as the Swiss index is the only IPDindex which is based on hedonic modelling, instead of appraisals, and should thus not suffer from appraisal bias. The least attractive riskreturn trade-offs were provided by the German and Swedish markets.

The correlation matrix for international property returns is illustrated in Table 4. All negative correlation coefficients have been bolded. The Finnish property market is positively correlated with all other property markets, except the German market. With eight out of thirteen countries (Canada, Denmark, France, Ireland, the Netherlands, Norway, Spain and Sweden) correlations were 0,8 or more suggesting no diversification benefits, and of the positive correlation coefficients only one, with Portugal, was low. Thus, it can be stated that the Finnish market did not provide significant diversification benefits under the studied period.

Altogether, the returns in the studied markets were strongly correlated with each other, the only negative correlations being with Germany or Portugal. Also Switzerland had some moderate correlations, for example with U.K. and U.S. 
Table 4. Correlation matrix for international property returns (hedged returns)

\begin{tabular}{|c|c|c|c|c|c|c|c|c|c|c|c|c|c|c|}
\hline & $\begin{array}{l}\frac{\pi}{\widetilde{\sigma}} \\
\text { శ్ } \\
\text { Uే }\end{array}$ & 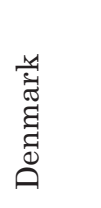 & 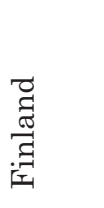 & 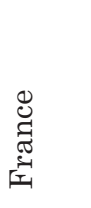 & 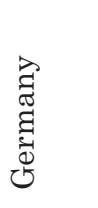 & 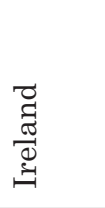 & 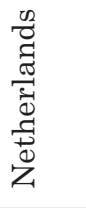 & 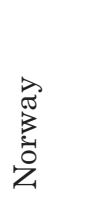 & 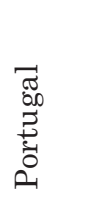 & 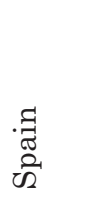 & 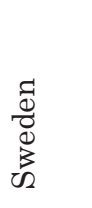 & 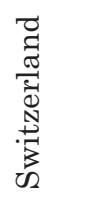 & نبِ & $\dot{\rho}$ \\
\hline Canada & 1,00 & & & & & & & & & & & & & \\
\hline Denmark & 0,88 & 1,00 & & & & & & & & & & & & \\
\hline Finland & 0,80 & 0,86 & 1,00 & & & & & & & & & & & \\
\hline France & 0,90 & 0,88 & 0,98 & 1,00 & & & & & & & & & & \\
\hline Germany & $-0,85$ & $-0,55$ & $-0,47$ & $-0,60$ & 1,00 & & & & & & & & & \\
\hline Ireland & 0,90 & 0,83 & 0,86 & 0,88 & $-0,79$ & 1,00 & & & & & & & & \\
\hline Netherlands & 0,82 & 0,91 & 0,95 & 0,96 & $-0,42$ & 0,75 & 1,00 & & & & & & & \\
\hline Norway & 0,98 & 0,89 & 0,90 & 0,96 & $-0,79$ & 0,94 & 0,88 & 1,00 & & & & & & \\
\hline Portugal & $-0,17$ & 0,07 & 0,08 & 0,06 & 0,57 & $-0,39$ & 0,31 & $-0,14$ & 1,00 & & & & & \\
\hline Spain & 1,00 & 0,90 & 0,85 & 0,92 & $-0,83$ & 0,93 & 0,85 & 0,99 & $-0,17$ & 1,00 & & & & \\
\hline Sweden & 0,98 & 0,91 & 0,91 & 0,97 & $-0,74$ & 0,90 & 0,92 & 0,99 & $-0,02$ & 0,98 & 1,00 & & & \\
\hline Switzerland & 0,35 & 0,55 & 0,75 & 0,69 & 0,14 & 0,31 & 0,81 & 0,47 & 0,69 & 0,39 & 0,54 & 1,00 & & \\
\hline U.K. & 0,89 & 0,57 & 0,53 & 0,68 & $-0,98$ & 0,77 & 0,52 & 0,83 & $-0,40$ & 0,86 & 0,80 & 0,01 & 1,00 & \\
\hline U.S. & 0,94 & 0,73 & 0,61 & 0,73 & $-0,97$ & 0,87 & 0,59 & 0,88 & $-0,44$ & 0,93 & 0,85 & 0,02 & 0,95 & 1,00 \\
\hline
\end{tabular}

Table 5 contains the country allocations in efficient portfolios. One should pay attention to the risk-return characteristics of the efficient portfolios, especially at the return levels of 4 to $6 \%$, where portfolio risk approaches zero. The efficient portfolios are dominated by German properties at the low to moderate risk levels and Portuguese properties in the moderate to high risk levels. The high negative correlations of these markets lead to significant diversification benefits in the portfolio.

The allocation to U.K. properties grows with the portfolio return, which is explained by the fact that the U.K. market provided high absolute returns with moderate risk. U.S. property enters the efficient portfolios at the lowest risk levels and Switzerland makes a short appearance in the return level of $8 \%$. It is also interesting to notice that of the fourteen countries, nine (Canada, Denmark, Finland, France, Ireland, Netherlands, Norway, Spain and Sweden) do not enter the efficient sets at all.
Table 5. Asset allocation in efficient international real estate portfolios (hedged returns)

\begin{tabular}{lllllll}
\hline $\begin{array}{l}\text { Portfolio } \\
\text { return }\end{array}$ & $4 \%$ & $6 \%$ & $8 \%$ & $10 \%$ & $12 \%$ & $14 \%$ \\
$\begin{array}{l}\text { Standard } \\
\text { deviation }\end{array}$ & $0 \%$ & $0 \%$ & $1 \%$ & $1 \%$ & $1 \%$ & $3 \%$ \\
\hline Canada & $0 \%$ & $0 \%$ & $0 \%$ & $0 \%$ & $0 \%$ & $0 \%$ \\
Denmark & $0 \%$ & $0 \%$ & $0 \%$ & $0 \%$ & $0 \%$ & $0 \%$ \\
Finland & $0 \%$ & $0 \%$ & $0 \%$ & $0 \%$ & $0 \%$ & $0 \%$ \\
France & $0 \%$ & $0 \%$ & $0 \%$ & $0 \%$ & $0 \%$ & $0 \%$ \\
Germany & $82 \%$ & $66 \%$ & $44 \%$ & $23 \%$ & $1 \%$ & $0 \%$ \\
Ireland & $0 \%$ & $0 \%$ & $0 \%$ & $0 \%$ & $0 \%$ & $0 \%$ \\
Netherlands & $0 \%$ & $0 \%$ & $0 \%$ & $0 \%$ & $0 \%$ & $0 \%$ \\
Norway & $0 \%$ & $0 \%$ & $0 \%$ & $0 \%$ & $0 \%$ & $0 \%$ \\
Portugal & $0 \%$ & $10 \%$ & $31 \%$ & $54 \%$ & $77 \%$ & $30 \%$ \\
Spain & $0 \%$ & $0 \%$ & $0 \%$ & $0 \%$ & $0 \%$ & $0 \%$ \\
Sweden & $0 \%$ & $0 \%$ & $0 \%$ & $0 \%$ & $0 \%$ & $0 \%$ \\
Switzerland & $0 \%$ & $0 \%$ & $2 \%$ & $0 \%$ & $0 \%$ & $0 \%$ \\
U.K. & $0 \%$ & $21 \%$ & $23 \%$ & $23 \%$ & $22 \%$ & $70 \%$ \\
U.S. & $18 \%$ & $3 \%$ & $0 \%$ & $0 \%$ & $0 \%$ & $0 \%$ \\
\hline
\end{tabular}


Most optimal allocations have extreme weights on few countries (Germany, Portugal and U.K.). The extreme weights are, however, not pure corner solutions, but are largely affected by the correlation structure of the asset returns. In practice such allocations might be unrealistic, and thus the optimisation was conducted using a $20 \%$ maximum allocation constraint. The results of the optimisation are illustrated in Table 6.

The use of constraints increases the number of countries in portfolios. Each optimal portfolio must consist of at least five countries, but in practise all optimal portfolios have an allocation to six countries. For Portugal and U.K., i.e. countries that had high allocations throughout the return spectrum in unconstrained portfolios, the constraint just limits the allocation to the highest level permitted. For Germany the case is different. The new countries in the portfolios change the dynamics of the portfolio, thus reducing the optimal allocations to German properties below the constraint level on return level of $20 \%$. When applying the allocation constraint also the Finnish real estate enters the optimal portfolio at the lowest return levels.

\section{Unhedged returns}

To see the effect of currency risk on the optimal portfolios, the analysis of international real estate portfolios was conducted using returns converted into euros. Seven of the studied countries (Finland, France, Germany, Ireland, Netherlands, Portugal, Spain) are part of the eurozone, so the adjustment for currency risk only affects the returns of the remaining seven countries (Canada, Denmark, Norway, Sweden, Switzerland, U.K. and U.S.). The summary statistics of the adjusted property data is illustrated in Table 7.

The changes in the risk-return profiles are marked, the size of effect, however, varies across countries. The effect is the largest for Switzerland and U.S., where the coefficient of variation multiplies to almost fourteen- and sevenfold, respectively. For Canada, Norway and U.K. the coefficient of variation approximately doubles. The only country where the effect is remains unsubstantial is Sweden. After the adjustments, Portugal and Netherlands provide the best risk-return trade-off in the sample.

Table 6. Asset allocation in efficient international real estate portfolios (hedged returns, allocation constraint 20\%)

\begin{tabular}{|c|c|c|c|c|c|c|c|c|}
\hline Portfolio return & $7 \%$ & $8 \%$ & $9 \%$ & $10 \%$ & $11 \%$ & $12 \%$ & $13 \%$ & $14 \%$ \\
\hline Standard deviation & $1 \%$ & $0,92 \%$ & $1 \%$ & $1,69 \%$ & $2 \%$ & $2,82 \%$ & $4 \%$ & $5,52 \%$ \\
\hline Canada & $0 \%$ & $0 \%$ & $0 \%$ & $0 \%$ & $0 \%$ & $16 \%$ & $20 \%$ & $20 \%$ \\
\hline Denmark & $0 \%$ & $0 \%$ & $0 \%$ & $0 \%$ & $0 \%$ & $0 \%$ & $0 \%$ & $0 \%$ \\
\hline Finland & $20 \%$ & $18 \%$ & $0 \%$ & $0 \%$ & $0 \%$ & $0 \%$ & $0 \%$ & $0 \%$ \\
\hline France & $0 \%$ & $0 \%$ & $0 \%$ & $0 \%$ & $0 \%$ & $0 \%$ & $0 \%$ & $15 \%$ \\
\hline Germany & $20 \%$ & $20 \%$ & $17 \%$ & $7 \%$ & $0 \%$ & $0 \%$ & $0 \%$ & $0 \%$ \\
\hline Ireland & $0 \%$ & $0 \%$ & $0 \%$ & $0 \%$ & $0 \%$ & $0 \%$ & $0 \%$ & $20 \%$ \\
\hline Netherlands & $19 \%$ & $5 \%$ & $20 \%$ & $20 \%$ & $20 \%$ & $20 \%$ & $4 \%$ & $0 \%$ \\
\hline Norway & $0 \%$ & $0 \%$ & $0 \%$ & $0 \%$ & $0 \%$ & $0 \%$ & $0 \%$ & $0 \%$ \\
\hline Portugal & $20 \%$ & $20 \%$ & $20 \%$ & $20 \%$ & $20 \%$ & $20 \%$ & $20 \%$ & $5 \%$ \\
\hline Spain & $0 \%$ & $0 \%$ & $0 \%$ & $9 \%$ & $20 \%$ & $20 \%$ & $20 \%$ & $0 \%$ \\
\hline Sweden & $0 \%$ & $0 \%$ & $0 \%$ & $0 \%$ & $0 \%$ & $0 \%$ & $0 \%$ & $0 \%$ \\
\hline Switzerland & $20 \%$ & $20 \%$ & $20 \%$ & $20 \%$ & $17 \%$ & $4 \%$ & $0 \%$ & $0 \%$ \\
\hline U.K. & $0 \%$ & $17 \%$ & $20 \%$ & $20 \%$ & $20 \%$ & $20 \%$ & $20 \%$ & $20 \%$ \\
\hline U.S. & $1 \%$ & $0 \%$ & $3 \%$ & $4 \%$ & $3 \%$ & $0 \%$ & $16 \%$ & $20 \%$ \\
\hline
\end{tabular}


Table 7. Summary statistics of property data (unhedged returns)

\begin{tabular}{llll}
\hline Country & $\begin{array}{l}\text { Average } \\
\text { return }\end{array}$ & $\begin{array}{l}\text { Standard } \\
\text { deviation }\end{array}$ & $\begin{array}{l}\text { Coefficient } \\
\text { of variation }\end{array}$ \\
\hline Canada & $12,62 \%$ & $17,22 \%$ & 1,36 \\
Denmark & $11,78 \%$ & $5,57 \%$ & 0,47 \\
Finland & $6,95 \%$ & $1,93 \%$ & 0,28 \\
France & $12,79 \%$ & $5,79 \%$ & 0,45 \\
Germany & $1,95 \%$ & $1,42 \%$ & 0,73 \\
Ireland & $15,56 \%$ & $10,18 \%$ & 0,65 \\
Netherlands & $9,29 \%$ & $2,16 \%$ & 0,23 \\
Norway & $11,29 \%$ & $10,39 \%$ & 0,92 \\
Portugal & $11,24 \%$ & $1,64 \%$ & 0,15 \\
Spain & $12,48 \%$ & $4,44 \%$ & 0,36 \\
Sweden & $8,36 \%$ & $7,43 \%$ & 0,89 \\
Switzerland & $3,67 \%$ & $3,81 \%$ & 1,04 \\
U.K. & $12,99 \%$ & $9,75 \%$ & 0,75 \\
U.S. & $5,90 \%$ & $19,11 \%$ & 3,24 \\
\hline
\end{tabular}

The correlation matrix for unhedged returns is provided in Table 8. Again, negative correlations are emphasised. The correlation coefficients for Germany and Portugal remain mostly negative, and the currency adjustment also turns some of the correlations for Switzerland negative. The effect of the currency adjustment on correlation coefficients varies across countries. Surprisingly for Canada, Norway, Switzerland and U.S. the correlation coefficients predominately increase, whereas for Denmark and U.K. the correlation coefficients mostly decrease.

The structure of efficient portfolios is illustrated in Table 9. The portfolios are again dominated by German and Portuguese property; whereas the U.K. property enters optimal portfolios only in the lower return levels. As for hedged returns, Denmark, Finland, France, Netherlands, Norway, Spain, Sweden and U.S.

Table 8. Correlation matrix for international property returns (unhedged returns)

\begin{tabular}{|c|c|c|c|c|c|c|c|c|c|c|c|c|c|c|}
\hline & 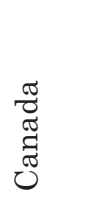 & 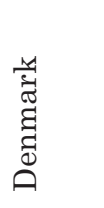 & 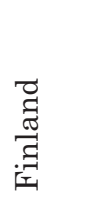 & 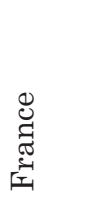 & 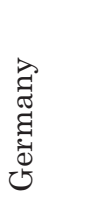 & 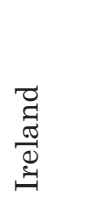 & 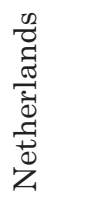 & 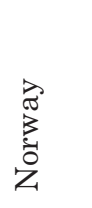 & 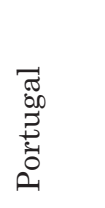 & 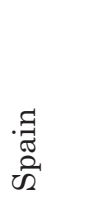 & $\begin{array}{l}\text { वี } \\
\frac{0}{0} \\
0 \\
\vdots \\
0\end{array}$ & 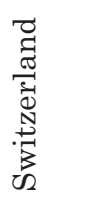 & بِّا & $\begin{array}{l}\dot{\varphi} \\
\dot{D}\end{array}$ \\
\hline Canada & 1,00 & & & & & & & & & & & & & \\
\hline Denmark & 0,46 & 1,00 & & & & & & & & & & & & \\
\hline Finland & 0,18 & 0,87 & 1,00 & & & & & & & & & & & \\
\hline France & 0,28 & 0,89 & 0,98 & 1,00 & & & & & & & & & & \\
\hline Germany & $-0,80$ & $-0,54$ & $-0,47$ & $-0,60$ & 1,00 & & & & & & & & & \\
\hline Ireland & 0,62 & 0,83 & 0,86 & 0,88 & $-0,79$ & 1,00 & & & & & & & & \\
\hline Netherlands & 0,14 & 0,92 & 0,95 & 0,96 & $-0,42$ & 0,75 & 1,00 & & & & & & & \\
\hline Norway & 0,15 & 0,55 & 0,29 & 0,43 & $-0,33$ & 0,17 & 0,57 & 1,00 & & & & & & \\
\hline Portugal & $-0,70$ & 0,09 & 0,08 & 0,06 & 0,57 & $-0,39$ & 0,31 & 0,52 & 1,00 & & & & & \\
\hline Spain & 0,60 & 0,90 & 0,85 & 0,92 & $-0,83$ & 0,93 & 0,85 & 0,51 & $-0,17$ & 1,00 & & & & \\
\hline Sweden & 0,03 & 0,77 & 0,95 & 0,96 & $-0,47$ & 0,75 & 0,94 & 0,43 & 0,22 & 0,81 & 1,00 & & & \\
\hline Switzerland & $-0,10$ & 0,05 & $-0,20$ & $-0,05$ & $-0,03$ & $-0,32$ & 0,10 & 0,86 & 0,59 & 0,03 & 0,02 & 1,00 & & \\
\hline U.K. & 0,66 & 0,70 & 0,63 & 0,77 & $-0,95$ & 0,81 & 0,65 & 0,55 & $-0,29$ & 0,93 & 0,67 & 0,21 & 1,00 & \\
\hline U.S. & 0,92 & 0,67 & 0,34 & 0,47 & $-0,84$ & 0,66 & 0,40 & 0,52 & $-0,40$ & 0,77 & 0,26 & 0,21 & 0,82 & 1,00 \\
\hline
\end{tabular}


Table 9. Asset allocation in efficient international real estate portfolios (unhedged returns)

\begin{tabular}{lllllll}
\hline Portfolio return & $4 \%$ & $6 \%$ & $8 \%$ & $10 \%$ & $12 \%$ & $14 \%$ \\
Standard deviation & $0,34 \%$ & $0,53 \%$ & $0,71 \%$ & $0,93 \%$ & $1,77 \%$ & $6,30 \%$ \\
\hline Canada & $3 \%$ & $4 \%$ & $5 \%$ & $6 \%$ & $1 \%$ & $0 \%$ \\
Denmark & $0 \%$ & $0 \%$ & $0 \%$ & $0 \%$ & $0 \%$ & $0 \%$ \\
Finland & $0 \%$ & $0 \%$ & $0 \%$ & $0 \%$ & $0 \%$ & $0 \%$ \\
France & $0 \%$ & $0 \%$ & $0 \%$ & $0 \%$ & $0 \%$ & $0 \%$ \\
Germany & $80 \%$ & $59 \%$ & $37 \%$ & $15 \%$ & $0 \%$ & $0 \%$ \\
Ireland & $0 \%$ & $2 \%$ & $3 \%$ & $2 \%$ & $17 \%$ & $64 \%$ \\
Netherlands & $0 \%$ & $0 \%$ & $0 \%$ & $0 \%$ & $0 \%$ & $0 \%$ \\
Norway & $0 \%$ & $0 \%$ & $0 \%$ & $0 \%$ & $0 \%$ & $0 \%$ \\
Portugal & $8 \%$ & $32 \%$ & $55 \%$ & $77 \%$ & $82 \%$ & $36 \%$ \\
Spain & $0 \%$ & $0 \%$ & $0 \%$ & $0 \%$ & $0 \%$ & $0 \%$ \\
Sweden & $0 \%$ & $0 \%$ & $0 \%$ & $0 \%$ & $0 \%$ & $0 \%$ \\
Switzerland & $0 \%$ & $0 \%$ & $0 \%$ & $0 \%$ & $0 \%$ & $0 \%$ \\
U.K. & $8 \%$ & $4 \%$ & $0 \%$ & $0 \%$ & $0 \%$ & $0 \%$ \\
U.S. & $0 \%$ & $0 \%$ & $0 \%$ & $0 \%$ & $0 \%$ & $0 \%$ \\
\hline
\end{tabular}

do not enter the efficient sets. Switzerland, which had a small allocation in the optimal hedged portfolios at the return level of $8 \%$, does not enter the portfolios, whereas Canada and Ireland do.

The allocations in the constrained portfolios are illustrated in Table 10. Again, the changes are not restricted to reducing allocations of some countries to the upper boundary (as for Portugal), adding new countries to the portfolio (e.g. the Netherlands, Finland) and leaving some out (e.g. U.K.), but the use of constraints changes the dynamics of the portfolio. In the constrained portfolio, the allocation to German property reduces to the set maximum on the risk levels of 6 and $8 \%$, but is clearly below the set maximum on the higher risk levels. For Portugal, the optimal allocations in the return levels of and above $8 \%$ are on upper boundary of the constraint, i.e. $20 \%$, whereas for the lowest return level, the allocation is markedly lower.

Dutch property, which did not enter the unconstrained portfolios, has an allocation of $20 \%$ on all risk levels. The case is similar for Finnish real estate, which has an optimal allocation of $20 \%$ on all other but the highest return levels. Other new countries in the constrained portfolios are Spain and France, which both have high allocations on the upper end of the return spectrum, and Sweden and Switzerland, which enter the portfolios at lower return levels. The countries that have moderate allocations in unconstrained portfolios, i.e. Canada and U.K, have decreased allocations in the constrained portfolios, whereas U.S. property enters the $4 \%$ return portfolio.

Table 10. Asset allocation in efficient international real estate portfolios (unhedged returns, allocation constraint $20 \%$ )

\begin{tabular}{lllll}
\hline Portfolio return & $6 \%$ & $8 \%$ & $10 \%$ & $12 \%$ \\
Standard deviation & $2,22 \%$ & $1,38 \%$ & $2,47 \%$ & $3,98 \%$ \\
\hline Canada & $0 \%$ & $2 \%$ & $1 \%$ & $0 \%$ \\
Denmark & $0 \%$ & $0 \%$ & $0 \%$ & $7 \%$ \\
Finland & $20 \%$ & $20 \%$ & $20 \%$ & $0 \%$ \\
France & $0 \%$ & $0 \%$ & $14 \%$ & $20 \%$ \\
Germany & $20 \%$ & $20 \%$ & $5 \%$ & $0 \%$ \\
Ireland & $0 \%$ & $0 \%$ & $0 \%$ & $13 \%$ \\
Netherlands & $20 \%$ & $20 \%$ & $20 \%$ & $20 \%$ \\
Norway & $0 \%$ & $0 \%$ & $0 \%$ & $0 \%$ \\
Portugal & $2 \%$ & $20 \%$ & $20 \%$ & $20 \%$ \\
Spain & $0 \%$ & $14 \%$ & $20 \%$ & $20 \%$ \\
Sweden & $13 \%$ & $0 \%$ & $0 \%$ & $0 \%$ \\
Switzerland & $20 \%$ & $4 \%$ & $0 \%$ & $0 \%$ \\
U.K. & $0 \%$ & $0 \%$ & $0 \%$ & $0 \%$ \\
U.S. & $4 \%$ & $0 \%$ & $0 \%$ & $0 \%$ \\
\hline
\end{tabular}




\section{CONCLUSIONS}

The purpose of this paper was to analyse, if the Finnish property market provided diversification benefits in its early years of internationalisation. In the Finnish mixed-asset context, both direct and indirect real estate investments had a large allocation in the set of efficient portfolios.

In the international real estate portfolio, the results varied depending on the constraints used. When there were no maximum allocation constraints, Finnish property did not enter the efficient portfolios regardless of the hedging strategy of the investor. When a maximum allocation constraint of $20 \%$ was set, the effects of hedging strategy started to play a more significant role in the results. For completely hedged returns, Finnish real estate offered diversification benefits at the $6 \%$ return level, whereas for unhedged returns, the allocation remained at the upper boundary of the allocation constraint until the return level of $10 \%$. Thus the results indicate that international investors were able to obtain diversification benefits in the Finnish property market during its early years of internationalisation.

\section{ACKNOWLEDGEMENT}

The author wishes to acknowledge Investment Property Databank and Institute for Real Estate Economics (KTI) for the data they provided, as well as Academy of Finland (project 122525) and Tekes - the National Technology Agency of Finland (project 40079/06) for the financial support. The author is also grateful to the editor of this journal and the two anonymous referees whose comments considerably improved the quality of this article.

\section{REFERENCES}

Addae-Dapaah, K. and Yong, G.L. (1998) Currency risk and office investment in Asia Pacific, Real Estate Finance, 15(3), pp. 67-85.

Addae-Dapaah, K. and Yong, C.C. (2000) Diversification of real estate investment in the AsiaPacific region, Pacific Rim Property Research Journal, 6(2), pp. 31-45.

Black, F. and Litterman, R. (1992) Global portfolio optimization, Financial Analysts Journal, 48(5), pp. 28-43.

Diaz, J. III and Wolverton, M.L. (1998) A longitudinal examination of the appraisal smoothing hypothesis, Real Estate Economics, 26(2), pp. 349-358.

Case, B., Goetzmann, W. and Rouwenhorst, K.G. (1999) Global real estate markets, cycles and fundamentals. Working Paper No. 99-03, Yale International Center for Finance.

Catella (2005) Market Review, Catella Property Oy., autumn 2005.

Catella (2008a) Market Review, Catella Property Oy., spring 2008.

Catella (2008b) Market Review, Catella Property Oy., autumn 2008.

Geltner, D. (1989) Estimating real estate's systematic risk from aggregate level appraisal-based returns, Journal of the American Real Estate and Urban Economics Association, 17(4), pp. 463-481.

Geltner, D. (1993) Estimating market values from appraised values without assuming an efficient market, Journal of Real Estate Research, 8(3), pp. 325-345.

Gordon, J. (1991) The diversification potential of international property investments, Real Estate Finance Journal, 7(2), pp. 42-48.

Hoesli, M., Lekander, J. and Witkiewicz, W. (2004) International evidence on real estate as a portfolio diversifier, Journal of Real Estate Research, 26(2), pp. 161-206.

Hudson-Wilson, S. and Stimpson, J. (1996) Adding US real estate to a Canadian portfolio: does it help? Real Estate Finance, 12(4), pp. 66-78. 
Jin, C., Grissom, T.V. and Ziobrowski, A.J. (2007) The mixed asset portfolio for Asia-Pasific markets, Journal of Real Estate Portfolio Management, 13(3), pp. 249-256.

Jones Lang Lasalle (2007) European Capital Market Bulletin 2007. Jones Lang Lasalle.

KTI (2008) The Finnish Property Market 2008. KTI Finland.

Lim, L.C., McGreal, S. and Webb, J.R. (2008) Institutional benchmarks for international real estate investment, Journal of Real Estate Portfolio Management, 14(2), pp. 93-104.

Markowitz, H.M. (1952) Portfolio selection, The Journal of Finance, 7(1), pp. 77-91.

McAllister, P. (1999) Globalization, integration and commercial property: Evidence from the UK, Journal of Property Investment and Finance, 17(1), pp. 8-26.

Newell, G. and Worzala, E. (1995) The role of international property in investment portfolios, Journal of Property Finance, 6(1), pp. 55-63.
Seiler, M.J., Webb, J.R. and Myer, F.C.N. (1999) Diversification issues in real estate investment, Journal of Real Estate Literature, 7(2), pp. 163-179.

Worzala, E. (1994) Overseas property investments: How are they perceived by the institutional investor? Journal of Property Valuation and Investment, 12(3), pp. 31-47.

Worzala, E. and Newell, G. (1997) International real estate: A review of strategic investment issues, Journal of Real Estate Portfolio Management, 3(2), pp. 87-96.

Worzala, E. (1992) International direct real estate investments as alternative portfolio assets for institutional investors: an evaluation. Unpublished dissertation, University of WisconsinMadison.

Wurtzebach, C. (1991) Looking at non-U.S. real estate, Real Estate Review, 21(1), pp. 48-54.

\section{SANTRAUKA}

\section{DIVERSIFIKACIJOS NAUDA SUOMIJOS KOMERCINIO NEKILNOJAMOJO TURTO RINKOJE}

\section{Heidi FALKENBACH}

XXI a. pradžioje Suomijos komercinio nekilnojamojo turto rinkoje sparčiai vyko tarptautiniai procesai. Remiantis portfelio teorija ir ankstesniais tyrimais apie tarptautines investicijas i nekilnojamaji turta, pagrindinis veiksnys, kuris skatina tarptautines nekilnojamojo turto investicijas - tai galimybè gauti diversifikacijos teikiamą nauda. Darbe aptariama, kokią naudą siūlè Suomijos nekilnojamojo turto rinka ankstyvaisiais internacionalizacijos metais. Kadangi kai kurie Suomijos nekilnojamojo turto rinkoje veikiantys tarptautiniai nekilnojamojo turto investuotojai užsiima tik nekilnojamuoju turtu, o yra ir tokių, kurie turi mišraus turto portfelius, diversifikacijos nauda nagrinejama ir pagal Suomijos mišraus turto portfelį, ir pagal tarptautini nekilnojamojo turto portfeli. 